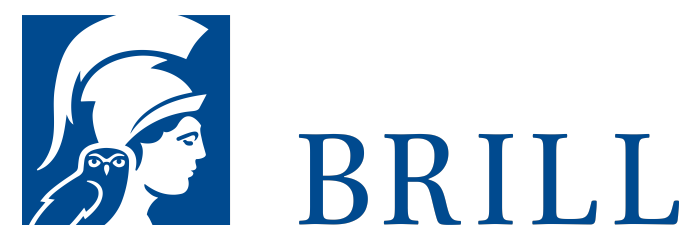

\title{
"Da stieg ein Baum"
}

Zur Poetik des Baumes seit der Romantik

\section{Author: Friedrich Wolfzettel}

Da stieg ein Baum" - neben seiner orphischen Bedeutung soll der Rilke-Vers auf die Entstehung einer autonomen Baumsymbolik seit der frühen Romantik verweisen. Die Bedeutung des Baummotivs in Mythos und Folklore hat längst die gebührende Aufmerksamkeit gefunden. In Dichtung und Literatur ist es hingegen nur gelegentlich gewürdigt worden, ohne dass der genannte Epochenumbruch berücksichtigt worden wäre. Die hier vorgelegten, bewusst essayistischen Überlegungen verstehen sich freilich nicht als eine unmögliche - Geschichte des Motivs; vielmehr entfalten sie nach einer historischen Hinführung die möglichen poetischen Funktionen in synchronen Raum der neueren Literatur seit der Entdeckung der pittoresken Ästhetik. Das Spektrum derunterschiedlich ausführlich - behandelten Beispiele reicht dabei von der russischen bis zur chilenischen Literatur, auch wenn die ,klassische' Romania im Zentrum steht.

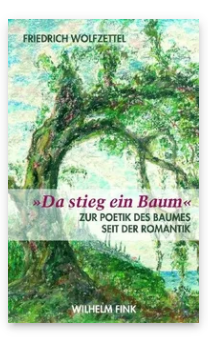

Pages: 157

Seiten

Language:

German

Subjects:

General,

Literature and

Cultural Studies

Publisher: Brill |

Fink

E-Book (PDF)

Released online:

3o Dec 2019

ISBN: $978-3^{-}$

8467-4507-6

List price

USD $\$ 24.00$

Paperback

Publication date:

22 Aug 2007

ISBN: 978-3-

7705-45०7-0

List price

USD \$24.00 
For more information see brill.com

Order information: Order online at brill.com +44330 333 0049 | customerservices@brill.com Submission information: brill.com/authors

Titles published by Brill | Fink, Brill | mentis or Brill | Schöningh: +49(o)715413279216| brill@brocom.de 